\title{
PENGEMBANGAN SUMBER BELAJAR BERBASIS ETNOMATEMATIKA DENGAN MODEL PjBL PADA MATERI BANGUN RUANG PRISMA
}

\author{
Thomas E. Kabu ${ }^{1 *}$, Prida N. L. Taneo ${ }^{2}$, Alfonsa M. Abi ${ }^{3}$ \\ ${ }^{1,2,3}$ Program Studi Pendidikan Matematika, STKIP SOE \\ *thomasedisonkabu02@gmail.com
}

Diterima: 15 September 2020 Disetujui: 06 November 2020 Dipublikasikan: 31 Januari 2021

\begin{abstract}
ABSTRAK
Penelitian ini adalah pengembangan sumber belajar berbasis etnomatematika dengan model pembelajaran Project Based Learning (PjBL) pada materi bangun ruang prisma. Tujuan dari penelitian ini adalah untuk mengetahui kevalidan, kepraktisan dan keefektifan sumber belajar berbasis etnomatematika. Sumber belajar yang dikembangkan berupa buku siswa dan Lembar Kerja Siswa (LKS) berbasis etnomatematika materi bangun ruang prisma. Jenis penelitian ini adalah penelitian dan pengembangan atau Research and Development $(\mathrm{R} \& \mathrm{D})$ dengan menggunakan model Borg and Gall. Penelitian ini dilaksanakan di SMP Kristen 1 Soe dengan budaya yang digunakan adalah hasil anyaman masyarakat Amanuban Barat berupa oko. Hasil penelitian menunjukkan bahwa sumber balajar yang dikembangkan valid dengan rata-rata persentase yang diperoleh $92,5 \%$ dan juga praktis digunakan dalam pembelajaran matematika dengan rata-rata persentase respon guru $86 \%$ dan respon siswa $95,5 \%$. Sumber belajar ini juga efektif berdasarkan hasil post-test yang menunjukkan bahwa rata-rata nilai tes pada kelas eksperimen adalah 76,96 jauh lebih besar dari kelas kontrol 61,70. Proporsi ketuntasan siswa pada kelas eksperimen adalah $83 \%$ ketuntasan secara klasikal. Berdasarkan hasil perhitungan skor gain normalisasi diketahui bahwa persentase peningkatan prestasi belajar matematika siswa kelas VIII SMP Kristen 1 Soe setelah diajarkan dengan sumber belajar berbasis etnomatematika dengan model PjBL adalah $60 \%$ berada pada kategori sedang.
\end{abstract}

Kata Kunci: etnomatematika, pengembangan, PjBL, prisma, prestasi belajar matematika, sumber belajar.

\begin{abstract}
This research is the development of learning resource based on etnomatematics with the learning model of Project Based Learning (PjBL) on the building material of prism room. The purpose of this study is to determine the validity, practicality and effectiveness of etnomatematics-based learning resources. Learning resources are developed in the form of student books and student worksheets based on ethnomatematics construct the prism room. This research type is research and development by using Borg and Gall model. This research was conducted in Junior High School Christian 1 Soe with the culture used is the woven of West Amanuban society in the form of oko. The results of this study indicate that the source of learning developed valid with the average percentage obtained $92.5 \%$ and also practical use in learning mathematics with the average percentage of teacher response $86 \%$ and $95.5 \%$ student response. This learning resource is also effective based on post-test results indicating that the average test score in the experimental class is 76.96 far greater than the control class 61.70. The proportion of students' completeness in the experimental class is $83 \%$ complete classically. Based on the results of the calculation of normalized gain score known that the percentage increase in mathematics learning achievement class VIII Junior High School Christian 1 Soe after taught with the source of learning based on ethnomatematics with PjBL model is $60 \%$ are in the category of being.
\end{abstract}

Keywords: etnomatematics, development, PjBL, prism, learning resources mathematics, learning achievement. 


\section{Pendahuluan}

Pendidikan pada dasarnya merupakan suatu upaya memberikan pengetahuan, wawasan, keterampilan dan keahlian tertentu kepada individu guna mengembangkan bakat serta kepribadiannya (Widyaningrum dkk, 2013). Satuan pendidikan yang diselenggarakan di Indonesia meliputi pendidikan formal, nonformal dan informal. Pendidikan formal melingkupi pendidikan dasar, pendidikan menengah maupun pendidikan tinggi yang berfungsi sebagai penyelenggara pendidikan (UU No. 20 Tahun 2003). Pendidikan diselenggarakan berjenjang dari sekolah dasar hingga perguruan tinggi. Salah satu bidang ilmu yang sangat penting disetiap jenjang pendidikan adalah Matematika.

Menurut James dan James, matematika adalah ilmu tentang logika mengenai bentuk, susunan, besaran dan konsep-konsep yang berhubungan satu sama lainnya (Suherman dkk, 2003:16). Matematika merupakan kegiatan pembelajaran yang diselenggarakan untuk memfasilitasi, meningkatkan kualitas dan prestasi belajar pada diri siswa (Winataputra dkk, 2007 : 1.18). Hamalik menyatakan bahwa prestasi belajar merupakan suatu hasil belajar yang dibutuhkan seseorang untuk mengetahui kemampuannya setelah mengikuti kegiatan pembelajaran (Rahmawati dan Marsigit, 2017).

Prestasi belajar matematika siswa SMP di Indonesia masih jauh tertinggal dengan negara lain. Hasil PISA (Programme for International Student Assessment) 2015 menunjukkan bahwa Indonesia berada pada peringkat 69 dari 76 negara, sedangkan hasil TIMSS (Trends in International Mathematics and Science Study) 2015 juga menunjukkan bahwa Indonesia berada pada peringkat 45 dari 50 negara. Prestasi belajar matematika siswa di Indonesia kurang memuaskan yang disebabkan oleh beberapa faktor, salah satunya adalah kemampuan pemahaman konsep matematika siswa yang masih rendah. Masalah rendahnya prestasi belajar matematika siswa juga terjadi di SMP Kristen 1 Soe.

Berdasarkan hasil wawancara dengan salah satu guru mata pelajaran matematika menyatakan bahwa nilai rata-rata UAS matematika kelas VIII semester I tahun pelajaran 2017/2018 adalah 60,45\%. Nilai tersebut menunjukkan prestasi belajar matematika siswa di SMP Kristen 1 Soe masih rendah. Beberapa faktor penyebab rendahnya prestasi belajar matematika siswa adalah pembelajaran masih bersifat abstrak dan sumber belajar yang digunakan tidak kontekstual. Sumber belajar yang digunakan berupa buku paket matematika dengan kajian materinya masih bersifat abstrak dan contoh yang digunakan tidak sesuai dengan kondisi nyata siswa. Salah satu cara yang dilakukan untuk mengatasi masalah keabstrakkan materi dalam sumber belajar matematika adalah perlu adanya pengembangan sumber belajar yang kontekstual bagi siswa sehingga digunakan sebagai referensi belajar dalam pembelajaran matematika.

Sumber belajar merupakan segala sesuatu yang telah ada maupun dikembangkan secara sistematis sehingga dapat dimanfaatkan dengan baik dalam proses pembelajaran (Jailani dan Hamid, 2016). Salah satu sumber belajar yang kontekstual adalah sumber belajar berbasis etnomatematika. Etnomatematika merupakan suatu pendekatan yang dapat digunakan untuk menjelaskan realitas hubungan antara budaya, lingkungan dan matematika sebagai rumpun ilmu pengetahuan (Astutiningtyas dkk, 2017). Sumber belajar berbasis etnomatematika adalah seperangkat materi atau substansi pembelajaran matematika yang mengaitkan materi pembelajaran matematika dengan budaya lingkungan siswa sehingga materi yang dipelajari lebih mudah dan praktis bagi siswa. Sumber belajar berbasis etnomatematika yang dikembangkan adalah buku siswa matematika dan Lembar Kerja Siswa (LKS). Buku siswa dan LKS berbasis etnomatematika yang dikembangkan mengkaji materi tentang bangun ruang prisma dengan manggunakan oko sebagai salah satu alat peraga berbasis etnomatematika. Sumber belajar tersebut divalidasi oleh tim validasi dan diimplementasikan dengan model Project Based Learning (PjBL). PjBL merupakan salah satu model pembelajaran yang menggunakan masalah sebagai langkah awal dalam mengumpulkan dan mengintegrasikan pengetahuan baru berdasarkan pengalamannya dalam beraktifitas secara nyata (Permendikbud, 2014). Tujuan dari pengembangan sumber belajar berbasis etnomatematika dengan model PjBL pada materi bangun ruang prisma adalah sebagai salah satu referensi belajar matematika yang valid, praktis dan efektif serta dapat meningkatkan prestasi belajar matematika siswa. 


\section{Metode Penelitian}

Metode penelitian yang digunakan adalah penelitian dan pengembangan atau Research and Development (R\&D). R\&D adalah metode penelitian yang digunakan untuk menghasilkan suatu produk tertentu dan menguji keefektifan produk tersebut (Sugiyono, 2015:297). Produk yang dikembangkan dari penelitian ini adalah sumber belajar matematika berbasis etnomatematika berupa buku siswa dan Lembar Kerja Siswa (LKS). Sampel dari penelitian ini adalah siswa kelas VIII SMP Kristen 1 Soe. Teknik pengambilan sampel yang digunakan adalah simple random sampling. Prosedur yang dilakukan dalam pengembangan sumber belajar ini adalah model Borg and Gall dengan langkahlangkahnya yaitu potensi dan masalah, pengumpulan data, desain produk, validasi desain produk, revisi validasi desain produk, uji coba skala kecil, revisi uji coba skala kecil, uji coba skala besar, revisi uji coba skala besar dan produk masal.

Instrumen pengumpulan data dalam penelitian ini adalah lembar validasi, kuesioner respon guru dan siswa serta tes berupa soal uraian. Lembar validasi digunakan untuk mengetahui kevalidan sumber belajar, kuesioner respon guru dan siswa digunakan untuk mengetahui kepraktisan sumber belajar serta soal tes digunakan untuk mengetahui keefektifan sumber belajar. Kevalidan sumber belajar dilihat berdasarkan hasil analisis lembar validasi yang dianalisis secara deskriptif dan kepraktisan sumber belajar dilihat berdasarkan hasil analisis kuesioner respon guru dan siswa yang dianalisis secara deskriptif. Kefektifan sumber belajar dilihat dari hasil post-test yang dianalisis menggunakan uji statistik parametrik yaitu uji-t satu sampel, uji-z dan uji-t sampel independen. Uji-t satu sampel digunakan untuk mengetahui ketuntasan individual, uji-z digunakan untuk mengetahui ketuntasan klasikal dan uji-t sampel independen digunakan untuk mengetahui peningkatan prestasi belajar matematika siswa. Kemudian dilakukan perhitungan skor gain normalisasi untuk melihat seberapa besar peningkatan prestasi belajar matematika siswa.

\section{Hasil Penelitian Dan Pembahasan}

Pengembangan sumber belajar ini dilakukan berdasarkan model pengembangan Borg dan Gall dengan tujuan menghasilkan sumber belajar matematika berbasis etnomatematika yang valid, praktis dan efektif. Sumber belajar yang dikembangkan berupa buku siswa dan LKS matematika berbasis etnomatematika dengan mengkaji materi tentang bangun ruang prisma. Pengembangan sumber belajar ini memiliki kelebihan yaitu mengembangkan sumber belajar yang kontekstual berbasis etnomatematika sehingga memperkenalkan budaya kepada siswa serta siswa dapat memahami keterkaitan matematika dengan budayanya dalam kehidupan sehari-hari. Konteks budaya yang digunakan dalam pengembangan ini adalah hasil anyaman masyarakat Amanuban Barat berupa oko. Materi yang dikembangkan dalam pengembangan sumber belajar ini adalah geometri pada pokok bahasan bangun ruang prisma. Sumber belajar berbasis etnomatematika diuji cobakan pada skala kecil dan skala besar dengan mengimplementasikan model pembelajaran Project Based Learning (PjBL).

Model PjBL diimplementasikan pada saat uji coba skala kecil yaitu siswa dibagi dalam bentuk kelompok dan diminta mendesain alat peraga berbentuk prisma dari karton dalam kelompok masingmasing. Uji coba skala besar, model PjBL diimplementasikan pada kelas eksperimen. Aktivitas kelompok yang dilakukan adalah masing-masing kelompok menggunting bentuk prisma yang dibagikan oleh guru untuk memperoleh jaring-jaring dari bentuk prisma tersebut. Kemudian jaringjaring prisma digambarkan dalam LKS lalu menghitung luas permukaan prisma dengan bantuan jaring-jaring bentuk prisma tersebut.

Data yang diperoleh dari penelitian ini adalah hasil analisis lembar validasi, kuesioner respon guru dan siswa serta nilai post-test siswa. Lembar validasi diisi oleh validator berdasarkan indikatorindikator validasi buku siswa dan LKS matematika berbasis etnomatematika. Kuesioner respon guru diisi oleh salah satu guru mata pelajaran matematika yang menilai tentang indikator dan tujuan pembelajaran pada sumber belajar yang dikembangkan. Sedangkan kuesioner respon siswa diisi oleh seluruh siswa pada kelas penelitian yang dipilih sebagai kelas uji coba skala kecil untuk mengetahui kepuasan siswa menggunkan sumber belajar berbasis etnomatematika. Data kevalidan dan kepraktisan sumber belajar berbasis etnomatematika dengan model PjBL pada materi bangun ruang prisma dianalisis secara deskriptif dan diperoleh hasilnya seperti pada Tabel 1. 
Range: Jurnal Pendidikan Matematika Vol. 2 No. 2 Tahun 2021

Thomas E. Kabu, dkk

Tabel 1. Hasil Kevalidan dan Kepraktisan Sumber Belajar

Berbasis Etnomatematika

\begin{tabular}{|c|c|c|c|c|}
\hline \multirow[b]{2}{*}{ Kategori } & \multicolumn{2}{|c|}{ Nilai (\%) } & \multirow[b]{2}{*}{ Rata-Rata } & \multirow[b]{2}{*}{ Kriteria } \\
\hline & Buku Siswa & LKS & & \\
\hline Validasi Ahli & $92 \%$ & $93 \%$ & $92,5 \%$ & Sangat valid \\
\hline Respon Guru & $85 \%$ & $87 \%$ & $86 \%$ & Sangat praktis \\
\hline Respon Siswa & $95 \%$ & $96 \%$ & $95,5 \%$ & Sangat praktis \\
\hline
\end{tabular}

Berdasarkan hasil pada Tabel 1., buku siswa dan LKS yang dikembangkan berada pada kriteria sangat valid dan sangat praktis. Kevalidan sumber belajar berbasis etnomatematika dilihat dari hasil analisis lembar validasi yang diisi oleh 8 orang validator yaitu 2 orang dosen matematika, 2 orang guru mata pelajaran, 2 orang teman sejawat dan 2 orang tokoh adat. Rata-rata persentase kevalidan sumber belajar berbasis etnomatematika yang diperoleh dari 8 orang validator adalah 92,5\% dengan kriteria sangat valid. Kepraktisan sumber belajar berbasis etnomatematika diketahui dari hasil analisis kuesioner respon guru dan siswa. Rata-rata persentase respon guru $86 \%$ dan respon siswa 95,5\% dengan kriteria sangat praktis. Kuesioner respon guru diisi oleh salah satu guru mata pelajaran matematika di SMP Kristen 1 Soe dan kuesioner respon siswa diisi oleh 22 orang siswa pada kelas VIII ${ }^{\mathrm{C}}$ yang dipilih sebagai kelas uji coba skala kecil. Setelah dilakukan penilaian oleh validator dan guru mata palajaran, maka tahap berikutnya adalah uji coba skala besar untuk mengetahui keefektifan sumber belajar berbasis etnomatematika. Uji coba skala besar dilakukan pada kelas VIII ${ }^{\mathrm{A}}$ dan VIII ${ }^{\mathrm{B}}$ sebagai kelas eksperimen dan kelas kontrol.

Keefektifan sumber belajar berbasis etnomatematika dilihat dari ketuntasan belajar siswa dan peningkatan prestasi belajar siswa pada kelas yang diajarkan dengan sumber belajar berbasis etnomatematika. Data yang dianalisis untuk mengetahui keefektifan sumber belajar adalah hasil posttest siswa. Hasil analisis post-test siswa, menunjukkan bahwa kelas yang diajarkan dengan sumber belajar berbasis etnomatematika tuntas secara individual dan klasikal. Hasil uji ketuntasan belajar siswa dapat dilihat pada Tabel 2.

Tabel 2. Hasil Uji Ketuntasan

\begin{tabular}{cccc}
\hline Ketuntasan & Nilai & Perbandingan & Kesimpulan \\
\hline \multirow{2}{*}{ Individual } & $\mathrm{t}_{\text {hitung }}=3,93$ & $3,93>1,72$ & Terima $\mathrm{H}_{1}$ \\
& $\mathrm{t}_{\text {tabel }}=1,72$ & & \\
\multirow{2}{*}{ Klasikal } & $\mathrm{z}_{\text {hitung }}=0,84$ & \multirow{2}{*}{$0,84>0,67$} & Terima $\mathrm{H}_{1}$ \\
& $\mathrm{z}_{\text {tabel }}=0,67$ & & \\
\hline
\end{tabular}

Berdasarkan hasil pada Tabel 2., kelas yang diajarkan dengan sumber belajar berbasis etnomatematika tuntas secara individual dan klasikal. Ketuntasan individual dilihat dari nilai $\mathrm{t}_{\text {hitung }}=3,93>\mathrm{t}_{\text {tabel }}=1,72$ yang berarti rataan prestasi belajar matematika siswa melampaui nilai KKM yang ditetapkan. Ketuntasan klasikal dilihat dari nilai $\mathrm{z}_{\text {hitung }}=0,84>\mathrm{z}_{\text {tabel }}=0,67$ yang berarti proporsi ketuntasan belajar siswa melampaui $75 \%$. Proporsi ketuntasan belajar siswa dilihat dari nilai rata-rata yang diperoleh yaitu $83 \%$ tuntas secara klasikal.

Peningkatan prestasi belajar matematika siswa di SMP Kristen 1 Soe diketahui berdasarkan hasil analisis nilai post-test pada kelas eksperimen dan kelas kontrol. Nilai rata-rata kelas eksperimen 76,96 jauh lebih besar dari kelas kontrol 61,70 sehingga dapat disimpulkan bahwa rataan prestasi belajar matematika siswa pada kelas eksperimen lebih baik dari pada kelas kontrol. Kemudian dilakukan perhitungan skor gain ternormalisasi untuk mengetahui seberapa besar peningkatan prestasi belajar matematika siswa pada kelas eksperimen. Hasil perhitungan skor gain normalisasi diperoleh nilai rata-rata pada kelas eksperimen dengan jumlah siswa 23 orang adalah 0.60 yang berada pada kategori sedang. Hasil penelitian ini sejalan dengan hasil penelitian Rahmawati dan Marsigit (2017) menyimpulkan bahwa pengembangan sumber belajar berbasis etnomatematika dapat meningkatkan hasil belajar matematika siswa. 


\section{Kesimpulan}

Berdasarkan hasil penelitian dan pembahasan, dapat disimpulkan bahwa sumber belajar matematika yang dikembangkan berupa buku siswa dan LKS berbasis etnomatematika dengan mengimplementasikan model PjBL dinyatakan valid, praktis dan efektif. Hasil penelitian ini menunjukkan bahwa sumber belajar yang dikembangkan valid dengan rata-rata persentase yang diperoleh $92,5 \%$ dan juga praktis digunakan dalam pembelajaran matematika dengan rata-rata persentase respon guru $86 \%$ dan respon siswa 95,5\%. Sumber belajar ini juga efektif berdasarkan hasil post-test yang menunjukkan bahwa rata-rata nilai tes pada kelas eksperimen adalah 76,96 jauh lebih besar dari kelas kontrol 61,70. Proporsi ketuntasan siswa pada kelas eksperimen adalah 83\% tuntas secara klasikal. Berdasarkan hasil perhitungan skor gain ternormalisasi diketahui bahwa persentase peningkatan prestasi belajar matematika siswa kelas VIII SMP Kristen 1 Soe setelah diajarkan dengan sumber belajar berbasis etnomatematika dengan model PjBL adalah $60 \%$ berada pada kategori sedang.

Saran dari peneliti yaitu siswa masih kesulitan menyelesaikan soal tentang luas permukaan prisma sehingga perlu pengembangan materi tentang bangun ruang prisma. Perlu adanya pengembangan lebih lanjut tentang objek etnomatematika lainnya agar memperluas konsep matematika yang berkaitan dengan etnomatematika.

\section{Daftar Pustaka}

Astutiningtyas, E. L., Wulandari, A. A. dan Farahsanti, I. 2017. "Etnomatematika dan Pemecahan Masalah Kombinatorik". Jurnal Math Educator Nusantara. 3 (2) : 59-134.

Jailani, M. S. dan Hamid A. 2016. "Pengembangan Sumber Belajar Berbasis Karakter Peserta Didik". Jurnal Pendidikan Islam. 10 (2) : 176-192.

PISA. (2015). Hasil PISA. [online]. http://www.kemdikbud.go.id/main/ blog/2016/12/peringkatdancapaianpisa- indonesia-mengalamipeningkatan. Diakses pada tanggal 22 Juni 2018.

Rahmawati, F. D. dan Marsigit. 2017. "Pengembangan Bahan Ajar Berbasis Etnomatematika untuk Meningkatkan Prestasi dan Motivasi Belajar Siswa SMP”. Jurnal Pendidikan Matematika. 6 (6) : 69-76.

Sugiyono. 2015. Metode Penelitian Kuantitatif, Kualitataif, dan $R \& D$. Bandung: Alfabeta.

Suherman, H. E., dkk. 2007. Strategi pembelajaran matematika kontemporer. Bandung: UPI.

TIMSS. (2015). Hasil TIMSS 2015. [online]. http://puspendik.kemendikbud.go.i d/seminar/upload/Rahmawati- Seminar\%2520Hasil\%2520TIMSS \%25202015,pdf. Diakses pada tanggal 22 Juni 2018.

Tim Penyusun. 2014. Permendikbud No. 58 Tahun 2014 tentang Kurikulum 2013 SMP/ MTs.

Widyaningrum, A. Z., Suyadi, G. dan Nurhanurawati. 2013. "Pengaruh Penerapan Pendekatan Kontekstual terhadap Kemampuan Pemahaman Konsep Matematis Siswa". Jurnal Pendidikan Matematika. 2(2): 69-75.

Winataputra, U. S., dkk. 2007. Teori Belajar dan Pembelajaran. Jakarta: Universitas Terbuka. 